SCHOLARS: Journal of Arts \& Humanities

[Peer-Reviewed, Open Access Scholarly Publication] Indexed in NepJOL; JPPS Star-Ranked Journal

Print ISSN: 2773-7829; e-ISSN: 2773-7837

eJournal Site: www.cdetu.edu.np/ejournal/
Central Department of English

Tribhuvan University

Kirtipur, Kathmandu, Nepal

URL: www.cdetu.edu.np

Original Research Article

\title{
Food Habits in the Indian Subcontinent: Making of Cultural Identities
}

\author{
Raj Kumar Baral ${ }^{1}$ \\ Swarnim Raj Lamsal ${ }^{2}$ \\ ${ }^{1}$ Central Department of English, Tribhuvan University, Kirtipur, Nepal \\ ${ }^{2}$ St. Xavier College, Kathmandu, Nepal
}

Article History: Submitted 10 June 2021; Revised 27 July 2021; Accepted 9 August 2021

Corresponding Author: Swarnim Raj Lamsal, Email: swarnim.l@ hotmail.com

DOI: https://doi.org/10.3126/sjah.v3i2.39416

Copyright 2021 () The Author(s). The work is licensed under a Creative Commons Attribution 4.0 International License (CC BY 4.0).

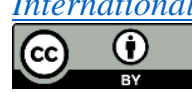

\begin{abstract}
This article analyses some popular eating habits in the Indian subcontinent, considering its diversity in its history, especially during the time of colonialism and its religion. Based upon the religious scriptures and postcolonial theorists like Shaobo Xie and Homi $K$. Bhabha, the article argues that food has its implications beyond the kitchen where it is cooked. Consciously or unconsciously, history and religion have dictated our food choices. Taken together, the references provide new insights into some of the common food items of the Indian subcontinent, showing them as distinct identity markers. Such analysis can help relate our food habits to a broad context and open new avenues to understand the cultural identity of humans through their dietary choices.
\end{abstract}

Keywords: Eating habits, Indian subcontinent, religion, colonialism, cultural identity

\section{Introduction}

We are foodies. Due to this common interest, we share a unique bond that goes beyond a conventional teacher-learner relationship. This interest and, undoubtedly, the relationship have helped both of us to see the nuances of life in a better way. As we keep searching for new cuisines, we also converse about the socio-economic realities of the world. We see that food has brought us together in such critical discourses.

It so happened during one of our meetings that we thought of writing about food, relating food to the history of the place and religion of the people. Owing to our recurring discussions, what we were seeking for was the answer to the question: does food have a history? We got our initial answer from M. F. K. Fisher. In The Gastronomical Me, Fisher contends that while writing about food, without her "willing," she is also telling about human beings and "their other deeper needs for love and happiness" (qtd. in Foreword, Counihan and Esterkik x). Through this statement, she clarifies the nexus that she sees between food, society and its needs. 
This was just a preliminary answer to the question that is related to food and its history that we were seeking. Although the relation between food and eating is age-long, it was an overlooked area in social sciences until a few years back. However, it is a burgeoning and complex area of study these days. In early days, some researches were conducted under the areas like biology, experimental psychology, physiology, physical anthropology and behavioural science, but their focus was to observe the human relationship to food vis-a-vis their behaviour, metabolic regulation and nutritional requirements. These core sciences only established this food- human relation from a utilitarian perspective rather than a cultural one. Stating the negligible interest of core sciences on the food-human relationship, Claude Fischler, in his article "Food, Self and Identity," argues that any given eating practice or foods in the past was evaluated only counting its nutritional value. If food was found to be somewhat significant, it was accepted as "wisdom of the body," but if any food was with no dietary significance, it was labelled as "irrational prejudice, superstitions or ultimately manifestations of ignorance" (275-276). Such kind of observation was found in Swarnim's first date.

During his first date, it was the very first look of the dinner that became the downturn of his expectations. He happened to see a large octopus on his date's plate. That disgusted him. She, too, frowned upon his deeply fried and chilly potatoes. As discussed earlier with Fischler's quote, Swarnim later realized that the disgust was a result of not understanding that food is a part of where one belongs to and what one has been brought up with. Expressed differently, food is related to our basic identity: Swarnim and his date considered each other's food to be biologically unfeasible. While for him, octopuses are fitting for navigating underwater only, for the lady, the excess of oil and frying was his ignorance of good eating habits.

However, what we realised is that the problem lies not only in a mere change in the eating habit. It is so because the food selection and eating habits, as mentioned earlier, have a complex phenomenon. In fact, food and cuisine are central components of collective belonging and identity. What and how we eat directly or indirectly relate us with our cultural identity. This human-food relationship operates a kind of particular system, where food no longer just becomes an item to satisfy our hunger, but a wide reflection of our history and religiosity.

\section{Location of Study}

With such kind of understanding, we have started seeing food in a new light. Our familiarity with the Indian subcontinent helped us to analyse the subcontinent, in its food habits, with more ease. So, we decided to assess its food habits in terms of history and religion. As being very diverse, the area is very much fit for our analysis. The religious belief is divergent here: each country has its own gods and forms of religious commandments in its ways of eating. Similarly, the ground of being or not being colonised by British (and/or other European countries) - and now, globalization as neocolonialism - is an indictment about the source of eating decorum to be followed. When these angles are analysed, the food choices become an issue to be observed in a continuum of time and place.

Before we advance towards our analysis, we would acknowledge that the Indian subcontinent is geographically divergent as well. Nepal, Afghanistan and Bhutan are landlocked countries while India, Maldives, Pakistan, Bangladesh and Sri Lanka are surrounded by sea. The place, too, marks a definite identity in terms of foods we eat. Humans grow up eating foods according to the geography they grow in; more importantly, the places humans keep on moving to leave an imprint in their food habits. Hanna Garth mentions, "economic and political system, new migration patterns, and 
movements of foods" as the responsible factors to destabilize the food-identity relations (2). That means, as people migrate, their food habits also align in the same process. So, their habits and customs of eating are proportional to the place where the individuals belong to at the given moment.

This can be seen with a basic contrast between foods available to sea-bound countries and landlocked countries. Being sea-bound means having more options to choose from for foods. The people living in such countries have a predilection towards fish and other sea creatures. That indicates that in sea-bound countries, sea becomes an additional reservoir of food. In contrast, owing to a heavy importance to vegetable farming in landlocked countries, veggies are less expensive than meat. For instance, as reported by Levitt et al, this is the same case in Afghanistan. In addition, the relative humidity and temperature of each locale affects what kind of food gets eaten raw and how food gets eaten. Similarly, cultural diversity of cookery may involve in the use of ingredients not ordinarily used in cooking elsewhere. So, as a whole, the place makes a significant impact on the food that we choose. However, the discussion is beyond the scope of this article.

\section{Food Habits and Colonialism}

Food habits of different cultures can be seen in a historical light. As foodies, we also realized that our appetite is a product of our body. Michel Foucault argues that even our body is a historically shaped being. He contends that our body is "poisoned by," among other things, "food or values" (87). That means, the body has its own history and a part of history is formed by the food we eat. Consequently, we can argue that the food habit is also relatable to the socio-economic-historical milieu of the given society. If it is so, we can think of seeing a particular history such as colonialism. The country where the highest influence of colonialism is seen in the Indian sub- continent might be India.

India was also colonized by Portugese, Dutch and Danish, but the impact of British colonization remained the most long-lasting. When they came to India, it became very difficult for them to acclamatise in a newer world. Moreover, they became the victim of diseases. To overcome the diseases, they thought "balanced diet was one of the ways" (Chowdhury 581). They realised the role of "air, food and drink, waking and sleep, motion and rest, evacuation and repletion, and the passions of the mind" to maintain and improve their health (Collingham 72). They also developed the habit of minimizing the consumption of meat and started eating sattvika, ${ }^{1}$ a Hindu food. To accustom on the given climate, they started eating native food items like boiled rice and fruits with discounted amount of meat varieties.

The British rulers were health conscious, but they were still the high consumers of beef and pork. Because of their eating habit, they faced health problems, blaming the climate/weather as the reason. Their eating menu included "bread, toast, butter, omelette, tongues, ducks, pigeon pies, chicken cutlets" including others (Johnson 73;

Stocqueler18). These food items sounded like clichéd and overused ones, considering that they were simply brought by their home side- there was nothing new flavor in the food. We saw that their food habits did-not end here. In the early days of the Raj, they also attempted to imitate the aristocratic eating style of Mughal rulers or Nawabs of India. They thought it was necessary because "what they perceived as Indian notions of how a ruling body should behave" (Collingham 81 ). As colonial agents, they showed

\footnotetext{
${ }^{1}$ Please note the discussion on different types of food in Hindu culture under the section "Food and Religion"
} 
Food Habits in the Indian Subcontinent: Making of Cultural Identities 16

their superiority by keeping a large number of servants and by living a luxurious life as the evidence of superior Britishness.

Foods became the cultural sites on which the bodily difference of the rulers and the ruled was sustained. The lavish eating habits got continued even after decolonization as evident from the menus prescribed for British breakfast and as found in Anglo-Indian guidebooks. In this context, it is worthwhile to quote Dipesh Chakrabarty, who argued, "eating was a ritualized expression of colonial ruling class culture signifying excess and plentitude" (167). As foods became a binary creator, the adjustment, adaptation and transformation over the variety, ingredients and styles of recipes had received a connotation of cultural imperialism, too. The adaptation of English and French cooking style as Chowdhury informs was to create and re-create a culinary experimentation that ultimately gave birth to a continental flavor, suiting the English taste and satisfying the cultural identity of the ruling class (584-85). The cultural value attached with food habits helped to differentiate the ruled with the rulers. As a whole, what we contended is that food is a cultural as well as historical product. This appetite ultimately makes our body historical. Lisa Heldke also contends that the cultural food colonialism exists in two forms: considering "food adventure as an exoticism" and by "turning the ethnic Other into a resource for the food adventurer's own use" (395). This is exactly what the British rulers did. They saw the Indian food exotic in the beginning and used it as a form of adventure, but later turned it for their own taste.

Certain portions of India were also colonized by Portugal that existed until 1961. The greatest effect of this process was seen in Goa, a city in southern India. Ayesha Saldanha observes that during their colony, the Portuguese left their mark on certain Indian cuisines either by "introducing new ingredients [like spices] to India" or by "introducing Portuguese dishes that were adapted to Indian culinary techniques and tastes." Such influence can be seen in Bandel Cheese which, most possibly, the Portuguese introduced in Bengal and the technique has survived for centuries, though certain local techniques and touches have been given to the art of cheese making.

These Portuguese dishes, which are now adapted into the local Indian tastes indicate that colonialism introduced food in one way, but then gradually got adapted to the local savour, ultimately transforming it into a hybrid food. In fact, postcolonial identity is formed by being hybrid: a mix of their native culture and the colonizers' culture. Homi K. Bhabha argues that while the colonizers create social control, they also fall prey to the "gaze" of the colonized. That means, the very "look of surveillance" by which the colonizers observe returns as the "displacing gaze of the disciplined" (127). There is not a neat and stable identity for both the colonizers and colonized - the colonizers, while defining the colonized as the Other, are actually defining themselves, as they are dependent upon that very notion for their self-assertion (after all, they say that they are the non-Other group, the central group). So the identity of the colonizers is an in-between type of identity. Raj Kumar Baral refers to Homi K. Bhabha's concept on hybridity as he states, "The in-between position of hybrid existence as a 'third space', which emerges in- between the traits of two mixed cultures. It is the space which incorporates the complexities of postcolonial realities" (30). Such hybridity is expressed in food habits as well.

A cuisine, in the Indian context, comprises hybrid dishes like curries, mulligatawny, kedgeree, chicken chop, pish-pash. Cecilia Leong-Salobir argues that Sahibs and Memsahibs of British Raj claimed the ownership of their dishes by consuming them at certain times and occasions. They also wrote about them, exchanged their recipes and critiqued them (48-49). Very interestingly, no other colonial dish was more consumed, debated and critiqued than the curry. With the curry-mutton, chicken, 
fish, prawns, or hardboiled ducks' eggs - came a dozen different side-dishes and savouries, which include different food varieties like "mango chutney from India, ikanbilis (tiny dried fish), red chilli sauce, a salty relish called "Bombay duck", shredded coconut, fried peanuts, chopped-up tomato and white onion, sliced banana, cucumber" (Leong-Salobir 12). All of these hybrid things suggest that food is a habit and when people need a change, they want to have experiments with their cuisines. This change is possible when the subjectivity of both the colonisers and the colonised is changed into a middle ground, creating a hybrid food. With this hybridity comes along food appropriation and this typically applies in the case of curry.

The curry is just a case in point to prove our contention that colonialism mixes the local taste with their own taste. That means, their identity, as Homi K. Bhabha says, is hybrid, even in food: their taste is their own identity, upon which it is associated with the colonial identity. This mix also defines both the coloinised and the coloniser with their new subjectivity of being hybrid agents.

Even if it is so, the ownership and power that food can provide is a cohesive force that can come only when some groups claim ownership. Written histories and popular cultures can be of great help, but more than that, the sharing, critiquing and constant experimenting with the ingredients is what shows the ownership of the food. So, food belongs to those who keep on trying and adapting the food to new tastes. It is the same with the colonial food as well: undoubtedly, colonial identity is related to what one eats and as the curry shows, food may begin with the colonizers, but it may end with the colonized as a cultural marker.

\section{Food Habits and Globalisation}

In Sri Lanka, the locals have already developed a similar-food habit like that of the westerners. According to Permani C. Weerasekara et al, obviously traditional eating habits have "countless health benefits," but now they "have been gradually replaced by the globalized food system of multinational corporations" which are the store-houses of the diseases, like "cancer, diabetes, cholesterol, and kidney disease epidemics in Sri Lanka" (30). This is not only the case of Sri Lanka; it is evident in foods like momo, pizza and burger, which have become popular not only in the Indian subcontinent, but also throughout the world. Such impact on food has invited many health hazards.

With globalization, which, itself, is termed as a neo-form of colonialism, the traditional dietary habits have changed. As Shaobo Xie contends, what is being "globalized" today in the "day of global capitalism" is "capitalism itself" (70). Xie takes the references from James Petras and Henry Veltmeyer, Fredric Jameson and some reports by World Bank and online portfolios and concludes that globalization is a "euphemistic respelling" of imperialism (58) and as such it turns "cultures into commodities" (67). It means that consumerism and capitalism is flowing globally with no sense of boundaries. Because of that, our social milieu has been global when it comes to food consumption. Now, globalization and its multinational companies have brought newer definitions of hunger, where consumerist culture is the only source of hunger fulfilment. Although such form of fulfilment can bring diseases, it is still influential.

In the case of Nepal, majority of the people used to have the habit of taking belly full of rice to satisfy their hunger, but these days, the pizza culture is gradually taking its place mainly in city areas. People have developed the restaurant culture to enjoy pizza, burger, chicken and all other western foods as their first choice. There are many castes and ethnic groups in Nepal with their own culture and food habits. Limbus, Rais, Magars, Newars and Gurungs, among others have the culture of drinking special local wine prepared at their own home. But the western culture has gradually affected their 
originality these days. They have started to drink beer and Coca-Cola instead of the selfprepared local wine. Such change of choice is what Xie calls as a result of "the rhetoric of colonization" (71), now manifested as globalization. The way that western foods and drinks are being popular is nothing but a way of following the western maxim that they are the best. Implicitly, our choices of food suggest where we want to belong and, in this west-dominated world, it means we want to be western.

Even if one feels that their traditional foods are being global, it is just a propaganda technique of capitalism, that, what Xie suggests as "localizing its globality to disarm resistance" (67). Dhido, a traditional Nepali food, can be a good example in this case. Once, this food was a poverty marker and stigmatized as a food only of the poor people. Gradually, this food entered into urban spaces and now is observed to have been a much-demanded food item in star hotels in Nepal as a prosperity marker. In fact, it is through globalization that dhido has been a reason that many tourists visit the local and star hotels of Nepal.

Similarly, coffee can be another example of the influential trend that can be seen due to the western influence. Coffee is a native drink of the western land. In England, during the seventeenth and the eighteenth centuries, coffee houses slowly developed as locales for social gathering. Although one of the reasons to have coffee may be its newness or the refreshment from the caffeine, it became another reason to meet, that is, an excuse for socializing. Similar kinds of coffee houses are slowly emerging in Nepal as well. As per a report by Krishna Prasain in The Kathmandu Post, the coffee consumption is gradually increasing in urban areas in recent years because of increasing incomes and growing number of coffee lovers (8). This has a positive impact in the coffee business; as a result, coffee shops are established in every nook and corner of the city. The coffee consumption is thought to be stylish and elitist, and coffee house is now a place of discussion of novice ideas and socialization. This is a trend influenced by the western world.

The above discussion on Dhido and coffee is an indictment to the point that globalization acts as a noble cause, popularizing certain local food or introducing some new taste to the world. But, in its hidden agenda, it is attacking the local culture as weak through foods. For instance, that Dhido became a popular food is owed to the tourists' interest in it. It means that unless the westerners do not taste certain local foods, they do not become worth eating. Similarly, the global proliferation of coffee is a replacement of all the local drinks and is an elitist marker. As such, coffee has become an elitist identification because it is a western drink.

Thus, whatever an individual eats, the food items are coloured with its history. In terms of colonization and globalisation, food choices are more implicitly tainted with the influence of western values and assumptions. Even if the advantages of colonialism and globalization are not overlooked, they remain sheer forces that dictate and even authenticate, at times, what and how one eats.

\section{Food Habits and Religion}

If the historical forces have their influences over food choices, the religious aspects, too, have a clear visible lens to affect what and how we eat. As food lovers do, we also make visits to religious restaurants. The following is a dialogue-that took place between us, as we entered a Muslim restaurant.

RKB: Swarnim, what would you like to eat?

SRL: Sir, to be honest, I am not very comfortable here. Muslim food practice is a taboo for me as a Hindu. I think so should be for you as well. How come, you are at so very ease here? 
Food Habits in the Indian Subcontinent: Making of Cultural Identities 19

RKB: Your discomfort is entirely comprehensible. But what you need to understand is that you are gazing at food only through your perspective. Food, after all, is not just a nutritional marker but also an identity marker. More than just a basic need for survival, food is ingrained in culture. Your thoughts are the product of the religious belief that you have been brought by and into. For instance, in her book Chilli and Cheese: Food and Society in Bhutan, Kunzang Choden highlights how importantly a food functions as "socio-economic signifier" and also elaborates the significance of foods like chilli and cheese which have meaning beyond their nourishment and focuses particularly in their religious and ritual values (44). The author explores regional agricultural and herding practices, the use of wild plants and the resulting food customs and habits of Bhutanese people. Her argument suggests that chilli, which might be a general seasoner, has a greater significance in Bhutan, only due to religious practices. I also remember Peter Berger, in "Food," writes "one person's affection is another's abomination." Stated differently, the same food that is common in someone's plate can be religiously despised by the other. Take beef, for instance. Would you ever dare to eat that?

SRL: (expressing disgust and fear) No! Undoubtedly, I would not dare to even think about eating, let alone eat. For us, cow is sacred-as scared as a mother and God.

RKB: (smiling) ah! That's the point. Eating beef in the Hindu community is a taboo, considered as sacrilegious but it is common in Muslim's kitchen as any other meat, except swine. For Muslims, cows do not hold the significance that is pervasive in the Hindu culture. So, food is cultural. Hindus believe that the cow slaughter and eating beef is a sin that will torment the sinner even in afterlife and another life. (Pausing) This strongly held belief in Hindu community is the cause of Hindu bigotry that leads many Hindu in India to have disgust over Muslims because they see beef as a food. In this regard, I again quote Berger who claims, "Hindu nationalist discourse" has created anger and violence against Muslims, and this appears to be a "natural" and "corporeal reaction." Thus, this difference as noted by Berger has further led people to make food a means to express wrath for each other and target religious sentiments.

SRL: Hmm! I see - so my discomfort is a way of expressing the wrath for Muslims, unconscious however it is?

RKB: Exactly. Our religion is so ingrained in our mind that we see our practices as the only right thing (Personal Conversation)

After this dialogue, RKB showed the eating habits as documented in the sacred books of the most-followed four religions, along with some other references, which made it clear that the eating habits in any individual's life is also based on religious commandments. For instance, in the Hindu Culture (religion followed mostly in Nepal and India), food is a common discourse. Patrick Olivelle states that the Indian culture has food in a seminal position from the earliest Vedic contemporary times. He notes that food is important in the said culture not only for physiology, but also for economy, social meetings, ethical concerns and even theological issues (367).

Olivelle also remarks that food is intertwined with daily thoughts of the Indians (particularly that of Hindus), and the classes of food "abhaksya, abhojya, anadya, and apeya" is one case to show that food has its discourse in Hindu culture (345). Both of the references from Olivelle suggest that the Hindu culture makes a distinction among edible 
and non-edible foods. When such norms come directly from religion, it becomes its own sort of standard to be maintained. Such standard ultimately links to our identities of who we are via our foods. A similar kind of discourse about food is also found in the Bhagavad Gita. In fact, food is one of the ways by which one can feel the presence of god. It is said: the devotees of the Lord are released from "all kinds of sins" because "they eat food which is offered first for sacrifice". Other people who prepare food for "personal enjoyment, verily eat only sin" (3.13). It means that food offered for the Lord called as prasada renders the devotees all kind of goodness.

Furthermore, the foods are classified into three different types based on their properties and effects that are rendered on humans: these are "sattvika", "raajasika", and "taamasika" (17.8-10). The "sattvika" food denotes the kind of food that "increase the duration of life, purify one's existence and give strength, health, happiness and satisfaction" and are "fatty, juicy, wholesome and pleasing to the heart" (17.8). Examples include fruits, vegetables and cereals. The "raajasika" food signifies that kind of food that is "bitter, sour, salty, hot, pungent, dry and burning" and are "dear to those in the mode of passion" and causes "distress, misery and disease" (17.9). The examples include caffeinated drink, fish and eggs. The taamasika food is the one that is "prepared more than three hours," that is "tasteless, decomposed, and putrid". They are related to those "in the mode of darkness" (17.10). Examples include meat, stale foods and frozen foods.

In the Hindu culture, animal slaughtering is thought to be a taboo, except it is done for Kali, "the ghastly form of material nature," before whom the "sacrifice [of animals] is "recommended" (Gita 3.13). Foods are offered at the temples of Kali and the nine other goddesses taken to be her manifestations, especially during festivals like Dashain. However, cow is not eaten, as the slaughter of cow is thought to be the "grossest type of ignorance" because "cow gives us all kinds of pleasure by supplying milk" (Gita 14.16). Thus, unrestrained meat eating is not allowed. Hindus do have certain ethnic foods as well, which as Jyoti Prakash Tamang and Delwen Samuel notice, have "social importance" for celebrations particularly during "festivals and other social occasions" (2).

In the Buddhist culture (followed in Bhutan, Sri Lanka, Nepal and India), animal slaughtering is not allowed. Tamang and Samuel observe that in the Buddhist religious dietary code, if the animal flesh is eaten, the animal should be killed by the nonBuddhists (2). According to Analayo, Buddhism is critical of sacrifice, especially of "the animal sacrifice of Vedic Brahmanism" (17). A Sutra of the DighaNikaya, the KutadantaSutta (no. 5), tells us that in an earlier existence the Buddha was the chaplain (purohita) of a king. In this capacity, he taught the king how to perform a sacrifice in which no bulls were slain, no goats or sheep, no cocks and pigs. Implicitly this story criticizes the Vedic sacrifice in which animals are killed.

The Buddhists and more specifically the monks are very strict vis-a-vis meat eating. As per the Buddhist rule, monks, as Tamang and Samuel mention, do not "eat anything solid" in the afternoon and are devoted for entire day fasting on the "new moon and the full moon" each month (2). As the Hindus, the Buddhists also believe that animals like cows are not to be slaughtered. They relish more on vegetables and fruits. However, the stricter categorization of food is not seen in the Buddhist culture.

In the Muslim practice, the food consumption is governed by some strict dietary laws and restrictions as mandated by The Quran. This is observable in the countries like Afghanistan, Pakistan, Maldives and Bangladesh. The Quran mentions that the following foods are generally forbidden to the Muslim: "dead meat, blood, the flesh of swine and that on which has been invoked the name of other than Allah." The book also states that 
animals are forbidden to eat if they are killed by these means: "strangling, or by a violent blow, or by a headlong fall, or by being gored to death; (partly) eaten by a wild animal; unless you are able to slaughter it (in due form); sacrificed on stone (altars); (forbidden) also is the division (of meat) by raffling with arrows." However, with all these restrictions, the book makes it easier by saying that "if any is forced by hunger, with no inclination or transgression, Allah is indeed Oft-Forgiving, Most Merciful." Combining these quotes, it is noticeable that the Muslim culture, like others, asks its disciples to dine with all adherences to its divine. There are certain restrictions but those boundaries can be crossed depending on the necessity, as Allah is benevolent.

As noted by Tamang and Samuel, the dietary laws of Muslims require that their foods are prepared "without any alcoholic beverages" (4). During Ramadan, a monthlong fasting, family members, friends and relatives share common and some extravagant meals after sunset.

In the Christian communities ${ }^{2}$, bread is a holy food that represents the body of Jesus and wine is drunk symbolizing his blood. Such kind of referencing comes directly from the Bible. The Christ himself speaks and in the Holy Communion, it is said, he took bread and broke it, and distributed the bread to his disciples saying, Take, eat; this is "My body." There is a similar saying for wine as well (New King James Bible, Matt. 26.26-7). The Christ declares that the blood is shed for "the remission of sins" (New King James Bible, Matt. 26. 28). In this way, the blood and bread are a medium to touch the Lord and ask his help to reduce the disciple's sins.

Such wine drinking is not without any kind of importance. Tamang and Samuel argue that drinking of wine is a symbol of "departure from the avoidance of blood," which was "proscribed in the Jewish dietary laws" (3). Thus, in order to create a separate identity from the previous Jewish diet, the Christians made a new form of food.

Not only bread and wine, but also eggs have some religious connotations in Christianity. As McWilliams mentions, eggs represent the resurrection of Jesus (qtd. in Tamang and Samuel, 3). In other words, foods are representative of two important life stages of the Christ- cruxification and resurrection.

The above discussion is not a mere list of the restrictions provided by the religions. The list and the preceding discussion suggest at least three things: first, foods are thought by each religion as the gifts or inscriptions of their gods; second, religious celebrations, including festivals, are a manifestation of the powers of the Lord. Abundant foods suggest that god is happy and so can be seen through the extravagant foods eaten and lesser restrictions seen during the celebrations; third, foods are classified as edibles and non-edibles not because of the qualities of the food themselves, but because of the way the religion has defined them. All of the three points suggest that food is a signature item of the divine - what we name as "relignature" - which an individual follows. When that individual gets multiplied, the belief about such classification becomes more consolidated and finally thought to be truth. The problem, with such confined definition of food, is that it generally avoids what other religions say.

\section{Conclusion}

The past studies on food have been generally confined to its utilitarian and metabolic uses. Even if other few researchers have talked about the socio-economic value of food, very few of them have taken the Indian subcontinent as their location of

\footnotetext{
${ }^{2}$ Christianity is a slowly grooming religion in this subcontinent, one of the reasons for which is Westernisation. So, at least till this date, Christianity is not a major religion of any country in this subcontinent.
} 
study. We have connected the area of our interest and love for food to make them a discourse; especially about the cultural identity resulted by history and religion. While doing so, what we found out is that food is never just an item, but an identity marker in itself. Upon deeply assessing the food items, what we can see is its peculiar history and religiosity, the dual aspects that generally come from the place of origin and shapes the broader cultural identity. In history, we are confined to the effect of colonialism and globalization, which not only turns the given food from one context to another (colonizer to colonized or vice-versa), but also makes food an economic and glocal entity. Such transformation also brings the newer definitions of hunger and dietary choices. The dietary choices are also dictated by the individual's and the nation's religion. While one might see food of other religions as despicable, they should realize that it is the same with other groups. Religion defines and even authenticates certain cuisines while subtracting others from the list of edible items. Whatever it is, history and religion are choices that cannot be easily dispensed with. They form a significant cultural identity of a given individual and thus food showcases one's cultural identity. As we eat, we chew not only the morsels of food, but also our cultural identity in terms of the religious footings we stand upon and the historical backdrop that we are brought up with.

\section{Works Cited}

A Dialogue. 16 Feb. 2021. Personal Conversation.

Analayo, Bhikkhu. Anālayo: The Genesis of the Bodhisattva Ideal. Hamburg UP, 2010.

Baral, Raj Kumar. "The Images of'In-between'in Derek Walcott's Poetry." International Journal of Humanities and Cultural Studies, vol. 6, no. 1, 2019, pp. 29-35.

Berger, Peter. "Food." Brill's Encyclopedia of Hinduism Online, 2018, https://dx.doi.org/10.1163/2212-5019.

Bhabha, Homi K. "Of Mimicry and Man. "The Location of Culture. $2^{\text {nd }}$ Indian Reprint. Routledge Classics, 2009, pp. 121-131.

Chakrabarty, Dipesh. Rethinking Working-Class History: Bengal, 1890-1940, Princeton UP, 2000.

Choden, Kunzang. Chilli and Cheese: Food and Society in Bhutan. White Lotus Press, 2008.

Chowdhury, Rituparna Ray. "The Imperial Diet of the British Raj: Food as Cultural Symbolism." Proceedings of the Indian History Congress, vol. 76, 2015, pp. 581-587. JSTOR, https://www.jstor.org/stable/44156624.

Collingham, Elizabeth M. Imperial Bodies: The Physical Experience of the Raj, c. 18001947. Polity Press, 2001.

Counihan, Carole and Penny Van Esterik. Foreword. Food and Culture: A Reader, edited by Counihan and Esterik, 3rd ed., Routledge, 2013, p. x.

Fischler, Claude. "Food, Self and Identity." Social Science Information, vol. 27, no. 2, 1988, pp. 275.

Foucault, Michel. The Foucault Reader, edited by. P. Rainbow. Pantheon Books, 1984.

Garth, Hanna. "Introduction: Understanding Caribbean Identity through Food." Food and Identity in the Caribbean, 2013, pp. 1-14.

Gummer, Natalie. D. "Sacrificial Sūtras: Mahāyāna Literature and the South Asian Ritual Cosmos." Journal of the American Academy of Religion, vol. 82, no. 4, 2014, pp. 1091-1126.

Heldke, Lisa. "Let's Cook Thai: Recipes for Colonialism." Food and Culture: A Reader, edited by Carole Counihan and Penny Van Esterik, 3rd ed., Routledge, 2013, pp. 394-408. 
Johnson, George William. The Stranger in India; or, Three Years in Calcutta, vol. 1. Henry Colburn, 1843.

Leong-Salobir, Cecilia. Food Culture in Colonial Asia: A Taste of Empire, Taylor \& Francis, 2011.

Levitt, Emily et al. Malnutrition in Afghanistan: Scale, Scope, Causes and Potential Response. The World Bank, 2010, https://openknowledge.worldbank.org/handle/10986/2518\%2015.

Olivelle, Patrick. "Food in India." Journal of Indian Philosophy, vol. 23, no. 3, 1995, pp. 367-380. JSTOR, https://www.jstor.com/stable/23447827.

--. . "Abhakșya and Abhojya: An Exploration in Dietary Language." Journal of the American Oriental Society, pp. 345-354. JSTOR, https://www.jstor.com/stable/3087629.

Prasain, Krishna. "Trendy Coffee Shops Take Kathmandu by Storm." The Kathmandu Post, 2019, p. 8, https://kathmandupost.com/money/2019/01/29/trendy-coffeeshops-take-kathmandu-by-storm.

Saldanha, Ayesha. "How the Portuguese Influenced Indian Cuisine." Global Voices, 27 Feb. 2014, https://globalvoices.org/2014/02/27/how-the-portuguese-influencedindian-cuisine/.

Stevenson, J. "On the Intermixture of Buddhism with Brahmanism in the Religion of the Hindus of the Dekkan." Journal of the Royal Asiatic Society of Great Britain and Ireland, vol.7, no. 1, 1843, pp. 1-8.

Stocqueler, Joachim Hayward. The Hand-book of India: A Guide to the Stranger and the Traveller, and a Companion to the Resident. WH Allen \& Co., 1845.

Tamang, Jyoti Prakash and Delwen Samuel. "Dietary Cultures and Antiquity of Fermented Foods and Beverages." Fermented Foods and Beverages of the World, edited by Tamang and Kasipathy Kailasapathy, CRC Press, 2010, pp. 140.

The Bhagavad-Gita. Translated and Transliterated by A.C. Bhaktivedanta Swami Prabhupada, 2nd ed. Bhaktivedanta Book Trust, 1986.

The New King James Bible. Thomas Nelson, 1982.

The Quran. Translated by Abdullah Yusuf Ali. Goodword Books, 2003.

Weerasekara, Permani.C., et.al. "Nutrition Transition and Traditional Food Cultural Changes in Sri Lanka during Colonization and Post-Colonization." Foods, vol. 7, no. 7, 2018, p. 30, https://doi.org/10.3390/foods7070111.

Xie, Shaobo. "Is the World Decentered?: A Postcolonial Perspective on Globalization." Global Fissures: Postcolonial Fusions. Edited by Clara AB Joseph and Janet Wilson. Rodopi, 2006, pp. 53-75. 